\title{
Improvement of the institutional model: Encouragement of innovative activity as a condition of growth of competitive ability in the regional economy
}

\author{
Irina S. Averina \\ Volgograd State University, \\ Institute of Economics and Finance, \\ Chair of the Economic Theory, \\ World and Regional Economics \\ Volgograd, Russia \\ averinais@volsu.ru
}

\author{
Marina E. Buyanova \\ Volgograd State University, \\ Institute of Economics and Finance, \\ Chair of the Economic Theory, \\ World and Regional Economics \\ Volgograd, Russia \\ buyanovame@volsu.ru
}

\author{
Elena Yu. Khoruzhaya \\ Volgograd State University, \\ Institute of Economics and Finance, \\ Chair of the Economic Theory, \\ World and Regional Economics \\ Volgograd, Russia \\ interec@ volsu.ru
}

\begin{abstract}
In the article the competitive positions of the Russian Federation determined by a relatively low level of the innovative activity of the economic actors in comparison with their foreign counterparts were analyzed. The theoretical model of the motivation of the entrepreneurs for the realization of the creative and innovative work was suggested. It includes the subjects, formal norms (legislation), informal rules (business culture typical of the economic community), incentives and limitations. The Volgograd region was chosen as the empirical base for the analysis of the model. Also the existing indices characterizing the innovative activity of the enterprises within the given region were studied. The contradictions arising at the functioning of the model under analysis were found. The recommendations for its improvement for the creation of the necessary conditions contributing to the growth of the competitive ability of the economy were suggested. The directions of the modernization mentioned above will create additional opportunities for the growth of the ratings positions of both a specific region and the country in the whole.
\end{abstract}

Keywords-innovations, competitive ability, region, model,encouragement

\section{INTRODUCTION}

In the modern world the innovations play an important role in the national economy of any country as they are one of the factors influencing the competitive ability of the economy both at the regional (meso) and at the national (macroeconomic) levels.
According to the world top list characterizing the global competitive ability of the countries 2016-2017 Russia occupied $43^{\text {th }}$ rank from 138 possible ranks outperforming only the developed economic nations like the USA (by 40 ranks), Germany (by 38 ranks), Great Britain (by 36 ranks), Japan (by 35 ranks), China (by 14 ranks) and so on [1].

The countries mentioned above outperformed Russia $\left(12^{\text {th }}\right.$ rank from 50) in 2016 by the level of the innovative character of the economy. Thus, for instance first five positions of the given rating were occupied by Germany, Japan, USA etc. [2].

This circumstance shows a significant discrepancy in the competitive ability and the innovative character of the economy of Russia and the leading economic nations.

The growth or the retention of competitive positions is one of the main directions of the economic policy, of an enterprise, of regional authorities and of the state in the whole.

This fact determines a considerable interest of national and foreign scientists the implementation of the research in the study of the innovative processes in the economy, factors determining them and the conditions originating from them.

The realization of such scientific research allows finding not only the constraining but also the encouraging factors and the conditions capable of catalyzing the innovative processes in the economy at different levels of the administration. It is 
also worth mentioning that the differentiation of territories determined by the historic and the economic discrepancies shows the importance of the implementation of the research from the regional aspect focused on the isolation of common characteristics and varieties among the regions of a country for a consequent development of the suggestions and the practical approbation of the existing experience with the specificity of the regional (meso) level of the national economy.

Despite the existing significant volume of scientific papers of the Russian and international scientific community in the sphere of the innovations the search of new directions of the encouragement of the innovative activity from the point of viewof various economic (Keynesian, marginalist, institutional) theories and so on remains important.

A number of papers are devoted to the study of the economic measures and tools influencing the level of the innovative activity of the economic actors at the government administration level.

Nevertheless equally important is the study of the ways of the increase of the level of the innovative economy from the point of view of the institutional theory as the efficiency of the introduction of the economic component generally depends aspects on the institutional norms and rules which determine it considerably.

The suggestion of the directions of the improvement of the models of the encouragement of the innovative activity in regions from the point of view of the institutional aspects is the aim of the research of this article.

\section{MATERIALS AND METHODS}

It is indispensible to compare the existing institutional models in this sphere having presented each of them from the point of view of the structural analysis (by means of the isolation of subjects with various targets, formal norms, informal rules, stimuli and limitations) for the development of the directions of the encouragement of the innovative activity in the regions of Russia.

The completeness of the research implies the use of the statistical method what determines the authenticity and the reliability of the obtained results.

The empirical base of the research are the data of the Federal Service for State Statistics of Russia, experimental assessments and calculations of the researchers published in the open publications and also the normative and legal acts of the federal and regional importance.

\section{RESULTS AND DISCUSSION}

Firstly let us suggest the authors' definition of the institutional model of the encouragement of the innovative activity for a more complete understanding of its specificity for the goal of the further research.

Thus when using the term "institutional model of encouragement" we mean a system of the ranked relations which are technically governed by formal norms and informal rules with the goal of the increase of the innovative regional economy and the economy of the country in the whole by means of use of a definite number of the encouraging measures and limitations.

Consequently the total structure of the institutional model of encouragement can be presented as the summation of:

- subjects having as the target goal the innovative sphere. In the given research these are the enterprises and the state in the form of federal, regional and local authorities;

- informal rules (business culture accepted in the economic community);

- formal norms (legislation in the sphere of the innovations);

- incentives encouraging the innovative processes and the limitations constraining the innovative activity of the economic actors.

It is worth carrying out the empirical analysis in compliance with the structure of the institutional model in the innovative sphere mentioned above by means of choosing the Volgograd region as the object of the analysis.

The innovative activity of the Volgograd region of the Russian Federation in the innovative sphere is characterized by the following indices (Table 1).

TABLE I. INDICES OF THE INNOVATIVE ACTIVITY OF THE VOLGOGRAD REGION IN 2012-2016

\begin{tabular}{|c|c|c|c|c|c|}
\hline \multirow[t]{2}{*}{ Index, unit of measurement } & \multicolumn{5}{|c|}{$\begin{array}{c}\text { Values of indices of the innovative } \\
\text { activity, } \\
2012-2016^{\text {a }}\end{array}$} \\
\hline & 2012 & 2013 & 2014 & 2015 & 2016 \\
\hline $\begin{array}{l}\text { Organizations carrying out } \\
\text { the R\&D }\end{array}$ & 38 & 45 & 47 & 53 & 46 \\
\hline $\begin{array}{l}\text { Internal expenses for } \mathrm{R} \& \mathrm{D} \text {, } \\
\text { million rubles }\end{array}$ & 3670 & 5294 & 8124 & 3418 & 3448 \\
\hline $\begin{array}{l}\text { Volume of innovative goods, } \\
\text { works, services, million } \\
\text { rubles }\end{array}$ & - & 6317 & 12985 & 17281 & 21341 \\
\hline $\begin{array}{l}\text { Developed progressive } \\
\text { industrial technologies, items }\end{array}$ & 0 & 2 & 1 & 0 & 0 \\
\hline $\begin{array}{l}\text { Introduced progressive } \\
\text { industrial techologies, items }\end{array}$ & 2055 & 2223 & 2404 & 2400 & 2511 \\
\hline $\begin{array}{l}\text { Share of the organizations } \\
\text { implementing the } \\
\text { technological, organizational } \\
\text { and marketing innovations in } \\
\text { the total number of the } \\
\text { organizations under analysis, } \\
\%\end{array}$ & 7,1 & 8,1 & 6,3 & 6,3 & 4,9 \\
\hline
\end{tabular}

A positive manifestation in total is the growth of the number of the organizations implementing the scientific research and development in the region from 2012 to 2016 more than 1,2 times. Also it is the increase of the volume of innovative goods, works and services during the analyzed period which consisted in the growth of the value of the given index by 3,38 times. The number of progressive industrial technologies also increased what is positive for the region which is considered to be as a subject of the federation with an average industrial development. 
Also a threatening trend of the reduction of the number of the own progressive technologies to 0 items in 2015-2016 is observed. The share of the organizations involved into the innovations in the region decreased by $2,2 \%$ (at the maximum of $8,1 \%$ ) and this tendency is considered to be a negative one.

The index characterizing the internal expenses for the research and development shows an instable dynamics. Thus this coefficient reduced by $6 \%$ in 2016 in comparison with 2012. If we analyze the total dynamics and if we take at the analysis year 2013 or 2014 as the basis year so the reduction of the numeric values in compliance with this index is more obvious (35\% and $58 \%$ correspondingly).

Thus despite the fact that in the region the situation is quite satisfactory with the innovation activity some problems are connected with a sharp drop of the entrepreneurial activity in the sphere of the development of the infrastructural component (Table II) due to the decrease of the expenses for innovations and the number of the own R\&D providing the stability of the production capacity of the region.

TABLE II. PARAMETERS OF THE INFRASTRUCTURAL CONSITUENT OF THE VOLGOGRAD REGION IN INNOVATION SPHERE IN 2015-2016

\begin{tabular}{|l|c|}
\hline \multicolumn{1}{|c|}{ Infrastructural objects } & $\begin{array}{c}\text { Quantitative } \\
\text { measurement, } \\
\text { items }\end{array}$ \\
\hline $\begin{array}{l}\text { Territory of the priority social and economic } \\
\text { development }\end{array}$ & 0 \\
\hline Clusters & 1 \\
\hline Government scientific centers & 0 \\
\hline Business incubators & 1 \\
\hline Innovation technological centers & 1 \\
\hline Technological parks & 0 \\
\hline Centers of the collective use & 0 \\
\hline Engineering centers & 2 \\
\hline Information and analytical centers & 0 \\
\hline Associations & 0 \\
\hline Information centers & 1 \\
\hline Innovation centers & 1 \\
\hline Consulting centers & 0 \\
\hline Technology transfer centers & 0 \\
\hline Centers for support of technologies and innovations & 0 \\
\hline Budget funds & 0 \\
\hline Other financial institutes & 0 \\
\hline
\end{tabular}

${ }^{\mathrm{b} .}$ National center for the monitoring of the innovative infrastructure of the scientific and technological activity of regional and innovative systems URL http://www.miiris.ru/regions/region_info.php?id=30 (Access date: 19.01.2018)

Having analyzed the general situation with the innovative activity existing today in the Volgograd region it is worth studying the formal norms, informal rules and the actions of the local authorities in the given region of Russia in the sphere of the innovation support of the economic actors of the region.

So from 2012 to 2017 a number of the legal acts dealing with the institutional changes in the innovative sphere were passed. It is the Law "About the government support of the innovative activity in the Volgograd region" with the corrections in 2015 [5]. The list of basic measures within the implementation of the economic policy of the region was adopted. In 2017 the Act of the Administration of the Volgograd region "About the approval of the order of the subsidizing of a part of the expenses of small and medium sized enterprises for the creation for the ongoing activity of the centers of the youth innovative creative works" [5].

However as the analysis of the full list of the corresponding normative and legal acts and programs adopted by the legal acts of the Volgograd region showed a large number of legal acts lost their force and were not replaced by new ones and consequently we can come to the conclusion about the weakening of the institutional base of the innovative activity in the region.

Thus in 2012 higher educational institutions of the Volgograd region created 19 small innovative enterprises which can also get the government support [5]. The center for the transfer of the technologies contributing to the introduction of new technologies into the industrial production and into the market was created [6].

For the period from 2014 to 2016 within the implementation of the Government program of the Volgograd region "Economic development and innovative economy" 2332 million rubles were allocated. Among them the funds from the federal budged accounted for 915 million rubles, funds from the regional budget accounted for 482 million rubles, money from the local budget accounted for 53 million rubles; money from extra-budgetary sources made up 882 million rubles [7].

It is worth also mentioning that the regional authorities are trying to support the innovative activity of small and medium sized business by means of the subsidizing of a part of the expenses of these companies.

Thus within the program mentioned above the sub program "Development and Support of small and medium sized enterprises in the Volgograd region" is being implemented. The volume of financing makes up 1,8 billion rubles.

In 2015 within this program the subsidies were allocated to 400 small and medium sized enterprises in the amount of more than 230 million rubles for the reimbursement of costs for the equipment and development of production ( 87 million rubles), 114 million rubles were paid for leasing contracts, 28 million rubles were given for the beginning of the entrepreneurial activity also through the municipalities, 17 million rubles were allocated for the participation in exhibitions and fairs.

In total in 2015-2016 the Administration of the region, the Russian Humanitarian Scientific Fund and the Russian Fund for Fundamental Research allocated the funds for 104 regional projects in the Humanities and for 91 projects in the sphere of the fundamental research for the total amount of 80 million rubles. Besides from 2014 to 2016 for the implementation of 145 projects of the young scientists and small innovative enterprises of the Volgograd region received from the federal budget 133 million rubles within the programs of the assistance for small enterprises in the scientific and technical sphere [8]. 
However it is worth mentioning that despite the existing corrections of the formal norms in the legislation of the Volgograd region for the analyzed period the study of the business practice shows that the entrepreneurs of the region assess the engagement of the enterprises into the innovative projects as a low one [9]. The experts give several reasons for such a situation:

- low demand for innovations from the part of the industrial enterprises;

- low interest of the manufacturers in the contact with the innovations developers or in the own research and development, in a more efficient consumption of the ready made innovations;

- preference for the cooperation with single investors and the students due to lower costs, lower normative and legal barriers and not with the owners of the business and large scientific organizations [10].

The reasons mentioned above that reduce the level of the innovative activity of a region can be explained by the following factors:

poorly developed legislation acts;
- low level of the legal knowledge of the
economic actors;
unequal distribution of the information in
the market of the innovative goods;
sphere; $\quad$ high risk of investments into the innovative
high level of corruption in the region $-46 \%$

\section{[11].}

Thus according to the survey of the Institute of Economic and Social Research carried out in 2014 the level of the corruption in the Volgograd region is high enough and makes $46 \%$ from maximal $100 \%$ [12].

Such an obstacle is reflected also in the total data in the Russian Federation where the corruption level in 2014 made up 27 ranks from 100 possible ranks $(0-$ high level of corruption, 100 - low level of corruption). According to this index Russia occupied in $2014136^{\text {th }}$ rank from 174 possible ranks [12].

The comparative analysis of the condition of the innovative activity in the Volgograd region and in other regions-leader of the Southern Federal district in 2015 showed that the Volgograd region can be described as a territory with 'an average innovative activity" occupying only the 45 rank (from 85 ) in the rating of the innovative activity among all the regions of Russia.

It is indispensible to clarify the indices which influenced a considerably low level of the innovative activity of the Volgograd region in comparison with the regions leaders of the Southern federal district by means of the use of the statistical data.
In 2015 the share of the organizations involved in the innovations in the regions of the Southern Federal district was the following:

$$
\begin{aligned}
& -\quad \text { In the Rostov oblast-9,9\%; } \\
& \text { - } \quad \text { In the Krasnodar krai - 6,5\%; } \\
& \text { - } \quad \text { In the Volgograd oblast- 4,9\% [3]. }
\end{aligned}
$$

The volume of innovative goods, works and services in 2015 in the regions mentioned above are characterized by the following amounts:

$$
\begin{array}{ll}
- & \text { Rostov oblast }-109 \text { billion rubles; } \\
\text { - } & \text { Krasnodar krai- } 7 \text { billion rubles; } \\
\text { Volgograd oblst }-17 \text { billion rubles [3]. }
\end{array}
$$

The analysis of the innovative activity in the Volgograd region allowed finding the following groups of the limitations:

$\begin{array}{ll}\begin{array}{l}- \\ \text { measures; }\end{array} & \text { Low efficiency of the government support } \\ - & \text { Lack of own finances and high interest rates }\end{array}$ for commercial loans;

- $\quad$ Absence or insufficiency of industrial areas with the lack of infrastructure for innovation activity;

- Complicated and time consuming procedures, long periods of time for the coordination of the projects and so on [14].

For the creation of favourable conditions of the stable economic development in 2012 a number of normative and legal acts reflecting the measures of the governmental support of the innovative activity of the enterprises in the Volgograd region were adopted. Similar measures taken in other regions of Russia have a higher efficiency what is proved by the ranks of the National Association for Innovations and for Development of Informational Technologies. That's why the analysis of the compatibility of the introduced incentives and conditions under which they will be realized was carried out.

The fact is that the differentiation of natural and economic constituents of the economic development of the regions of the Russian Federation determines the unequal results in the innovative sphere and this in its turn implies the use of tools and encouragement measures or of the constraints corresponding to the specific peculiarities and the level of the economic development in a region.

\section{CONCLUSION}

In the foreign and national practice the number of measures and tools contributing to an innovative development of region has been used. However taking into account the condition of the innovative constituent in the Volgograd region the following measures for the improvement of the institutional model of the encouragement of the innovative activity are suggested: the legal and normative and also infrastructural ones. 
A. Within the normative and legal sphere the follwing measures shoud be taken:

- Improvement of the legislation in the innovative sphere;

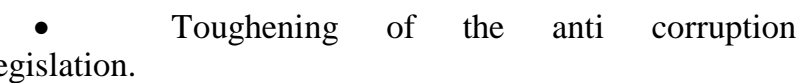

B. Within the infrastructural direction it is necessary to do the following:

- $\quad$ To divide the research and development into the spheres;

- $\quad$ To create the service of the R\&D purchaser at different levels (federal, regional and microlevel);

To build the engineering centers ensuring the transfer of the progressive technologies at different economic levels;

To create regional analytical centers for the monitoring of the innovative activity;

To improve the informational direction (spreading of the data about the innovations for potential innovators and the interested persons for the innovative production) within the coordination of the process of the creation and the functioning of the specialized regional centers;

To create a common federal base of innovations using identical regional bases (suggestion of the innovations suppliers);

To create the common base of the search queries for innovative products from the part of the economic actors at the microlevel (from enterprises).

Thus for the solution of the problem of a low innovative activity which determines an insignificant competitive ability of national goods and services in the world market and it is necessary to use not only the economic measures of encouragement but also the institutional changes both at the macrolevel and before all at the regional (meso) level. Thus the existing disparity of the regions of the Russian Federation engenders the necessity of the specification of the measures and tools taken within the regional and innovative processes.

The classification of the regions according to the level of the innovative activity leads to the necessity of the comparison of their infrastructural, financial and institutional constituents for finding general traits and lacking elements within the functioning of regional innovative system of each of them.

The analysis made in the paper allows determining the reasons of the regional differentiation of the level of the innovative activity and allows suggesting the directions of the solution of such a problem with a view to the increase of the competitive ability of regional economies and the national economy of the country in the whole.

\section{References}

[1] Vsemirnyi ekonomicheskii forum: reiting global'noi konkurentosposobnosti 2016-2017 [World economic forum: rating of the global competitive ability 2016-2017]. Available at: http://gtmarket.ru/news/2016/09/28/7304 (reference date: 27.01.2018)

[2] Bloomberg vklyuchil Rossiyu v top-50 samykh innovatsionnykh ekonomik mira [Bloomberg included Russia into top 50 most innovative economies of the world]. Available at: https://ria.ru/economy/20160119/1361949093.html (reference date: 27.01.2018).

[3] Federal'naya sluzhba gosudarstvennoi statistiki [Federal service for state statistics]. Available at: http:// gks.ru (reference date: 28.01.2018).

[4] Natsional'nyi tsentr po monitoringu innovatsionnoi infrastruktury nauchno-tekhnicheskoi deyatel'nosti i regional'nykh innovatsionnykh sistem [National center for the monitoring of the innovative infrastructure $o$ the scientific and technical activity and reginal innovative systems]. Available at: http://www.miiris.ru/regions/region_info.php?id=30 (reference date: 27.01.2018).

[5] Informatsionno-pravovoi portal «Garant. RU» [Information and legal portal "Garant.ru"]. Available at: http://www.garant.ru (reference date: 27.01.2018).

[6] Volgogradskaya oblastnaya duma [Volgograd regional duma]. Available at: http://volgoduma.ru/informacziya-press-sluzhby/press-relizy/6919press-reliz-s-19-po-22-marta-2012-goda.html (reference date: 27.01.2018).

[7] Gosudarstvennaya programma Volgogradskoi oblasti «Ekonomicheskoe razvitie i innovatsionnaya ekonomika» na 2014-2016 gg. [Government program of the Volgograd region "Economic development and innovative economy" for 2014-2016]. Adopted by the Decree of the Volgograd region dated December, 2013 N 696-п. - Available at: http://smb.gov.ru/files/images/Постановление\% 20Правительства\%20 Волгоградской\%20области\% 20от\%209\%20декабря\%202013\%20г.\% 20N\%20696-п.pdf (date of reference: 27.01.2018).

[8] Ledeneva, M.V., Parfenova, M.V. Mery gosudarstvennogo stimulirovaniya innovatsionnoi deyatel'nosti malogo i srednego predprinimatel'stva v Volgogradskoi oblasti i otsenka ikh effektivnosti [Measures of the government encouragement of the inovative activity of small and medium sized business in the Volgograd region and the assessment of their efficiency], Economy of education, 2016, №6, pp.41-58.

[9] Bukareva, N.I. Innovatsionnaya aktivnost' organizatsii Volgogradskoi oblasti [Innovative activity of the organizations of the Volgograd region]. Available at :http://srtv.gks.ru/wps/wcm/connect/rosstat_ts/srtv/resources/aaaf9d0043 d4e836b447b7fa17e1e317/Доклад_на+сайт.pdf (refernce date: 27.01.2018).

[10] Investitsionnyi forum: innovatsii dlya biznesa [Investment forum: innovations for business]. - Available at: http://www.innovbusiness.ru/NewsAM/NewsAMShow.asp?ID=16016 (reference date: 27.01.2018).

[11] "Otsenka vospriyatiya naseleniem proyavlenii korruptsii 2014" [Assessment of the perception by the population of the corruption manifestations]. Available at: http://ag.volgograd.ru (date of reference: 28.01.2018).

[12] Indeks vospriyatiya korruptsii 2014 [Index of the corruption perception 2014]. Available at: https://transparency.org.ru/research/indeksvospriyatiya-korruptsii/indeks-vospriyatiya-korruptsii-2014-otsenkarossii-upala-na-odin-ball.html (reference date: 27.01.2018).

[13] Natsional'naya assotsiatsiya innovatsii i razvitiya informatsionnykh tekhnologii [National association of the innovations and the developmetn of informational technologies]. Available at: http://innomir.ru/russia/173-2015-08-13-13-55-55 (reference date: 27.01.2018).

[14] Komitet ekonomicheskoi politiki i razvitiya Volgogradskoi oblasti [Committee of the economic policy and developemnt of the Volgograd region]. Available at: http://economics.volgograd.ru/currentactivity/cooperation/news/158589/ (reference date: 28.01.2018). 